\title{
doispontos:
}

\section{Juristocracia Midiática}

\author{
Joel Thiago Klein \\ Professor do Departamento de Filosofia da UFPR \\ Pesquisador do CNPq \\ jthklein@yahoo.com.br
}

Resumo: Este artigo apresenta o conceito de juristocracia midiática como uma categoria política que indica uma desfiguração dos ideais normativos de democracia e de estado de direito. Essa categoria se apresenta como o desenvolvimento, por um lado, do conceito de juristocracia analisado e elaborado por Hirschl e, por outro lado, da categoria de democracia plebiscitária analisada e elaborada por Urbinati. Argumenta-se que essa categoria permite enquadrar alguns dos problemas políticos pelos quais o Brasil vem passando na última década.

Palavras-chave: Juristocracia midiática, democracia, estado de direito, desfigurações

\begin{abstract}
In this paper I present the concept of juristocracy of audience as a political category that indicates a disfiguration concerning the normative ideals of democracy and the rule of law. On the one hand, the category of juristocracy of audience is developed from Hirschl's analysis and research on what he calls juristocracy, one the other hand, it is also developed from Urbinati's concept of plebiscitary democracy. I argue that this category helps us to understand some of the political problems that are happening in Brazil in the last decade.
\end{abstract}

Key-words: Juristocracy of audience, democracy, rule of law, disfigurations 
Este artigo propõe a categoria político-filosófica de juristocracia midiática para compreender e avaliar um fenômeno político em curso no Brasil. Como normalmente acontece com conceitos político-filosóficos, esse também não é um conceito absolutamente novo, mas se enraíza em categorias políticas já utilizadas para indicar duas distintas patologias ou desfigurações políticas. De um lado, adota-se aqui a categoria de jusristocracia apresentada e criticada por Hirschl (2004), nesse sentido a primeira seção desse artigo se propõe a fazer uma breve reconstrução das teses apresentadas por esse autor. Na segunda seção, retomase de Urbinati a categoria da democracia plebiscitária como sendo uma das desfigurações da democracia contemporânea. Na terceira seção apresenta-se a proposta de contribuição conceitual original desse artigo, qual seja, a construção da categoria de juristocracia midiática como sendo uma dupla-patologia ou uma dupla desfiguração política que ameaça tanto os valores democráticos, quanto os valores do estado de direito. Busca-se apresentar as características centrais desse conceito recorrendo-se também a uma indicação do que ocorreu na recente história política brasileira. Finalmente, faz-se algumas breves considerações finais, nas quais se chama a atenção da proximidade da juristocracia midiática com algumas características do fascismo do início do século XX.

\section{A juristocracia}

No livro Em direção à juristocracia (Towards juristocracy, 2004) Hirschl define juristocracia como o resultado de um amplo processo de transferência de poder político de instituições representativas para o poder judiciário. Tal fenômeno ainda estaria em andamento e não completamente acabado, mas ocorreria em escala global, podendo ser visto em mais de oitenta países e em diversas instituições supranacionais (HIRSCHL, 2004, 1). Como indicado pela terminologia, trata-se do estabelecimento de um governo do poder judiciário.

O detalhado estudo de Hirschl a partir da análise de quatro casos de constitucionalização (Canadá, Israel, África do Sul e Nova Zelândia) mostra como há uma grande lacuna, de um lado, entre o benevolente discurso predominante de que o processo de constitucionalização de direitos é um processo natural e progressista das democracias e, de outro lado, a realidade cotidiana da atuação das cortes nesses países. $\mathrm{O}$ fenômeno da constitucionalização de direitos e a transferência de poderes para o judiciário se apresenta, na realidade, como uma forma de retirar importantes decisões políticas da arena política, especialmente aquelas que interferem no status quo da sociedade, e levá-las para um lugar "mais seguro", longe do alcance político do povo. Nesse sentido,

O empoderamento judicial através da constitucionalização de direitos pode oferecer uma eficiente solução institucional para grupos influentes que buscam preservar a sua hegemonia e que, dada uma erosão no seu suporte popular, podem acreditar que seja uma estratégia desvantajosa aderir a processos majoritários de escolha política. (...). Portanto, a constitucionalização dos direitos é frequentemente não um reflexo de uma revolução genuinamente progressista na política; mas é evidente que a retórica dos direitos e da revisão judicial foi apropriada por elites ameaçadas para suportar sua própria posição na política. (HIRSCHL, 2004, 12)

Em outras palavras, o fenômeno da juristocracia é "uma tendência mundial de empoderamento judicial por meio da constitucionalização", o qual

\footnotetext{
precisa ser entendido como parte e parcela de um processo de larga escala em que a autoridade das decisóes políticas é continuamente transferida pelas elites hegemônicas das arenas de decisão política majoritárias para corpos semiautônomos e profissionais, especialmente para insular suas preferências políticas das vicissitudes da política democrática. (HIRSCHL, 2004, 16)
}

Melhor dizendo, daquilo que as elites hegemônicas consideram como sendo uma vicissitude.

Segundo Hirschl (2004, 12; 49; 213s.), seriam três os grupos que fomentam e defendem o modelo da juristocracia: o primeiro grupo se constitui de elites políticas ameaçadas pelo processo democrático, de modo que elas buscam na juristocracia uma forma de preservar ou de melhorar sua hegemonia política 
ao insular o processo de decisão política em geral e suas preferências políticas em particular do processo democrático enquanto que elas ainda podem utilizar a retórica de estarem defendendo e professando a democracia; o segundo grupo se constitui de elites econômicas que veem na constitucionalização de direitos, especialmente do direito de propriedade, de mobilidade e direitos profissionais, um meio de colocar limites na ação do governo e promover o livre mercado com uma agenda amigável; já o terceiro grupo se constitui de elites judiciais e supremas cortes que buscam aumentar sua influência política dentro do estado e sua reputação internacional.

Apesar da retórica de uma revolução democrática, o fato é que, nos quatro casos investigados (Canadá, Israel, África do Sul e Nova Zelândia), Hirschl constata que a partir da constitucionalização de direitos e do empoderamento das cortes não houve nenhuma melhora na proteção dos direitos sociais ou da qualidade de vida da população. "Na verdade, a constitucionalização vem servindo mais frequentemente como um meio efetivo de proteger a esfera econômica das tentativas de reduzir a disparidade socioeconômica através de meios regulatórios e redistributivos" (HIRSCHL, 2004, 218). Além disso,

\footnotetext{
Canalizar os processos de justiça social para as cortes tem um considerável potencial para prejudicar movimentos de reforma social por pacificar os ativistas com a ilusão de mudança e desviando recursos do processo político e das estratégias de pressão por meio das quais mudanças mais substancias poderiam ser alcançadas. A natureza institucional, pro-status-quo e inerentemente pacifista do sistema legal é especialmente significativa quando reinvindicações de justiça que tem implicações potencialmente revolucionárias para a redistribuição de riqueza e poder (como as da reconstrução do pós-apartheid na África do Sul ou as disputas sobre os direitos de povos indígenas em sociedades colonizadas) são transferidos da esfera política, que é potencialmente aberta, para a esfera judicial, que é inerentemente mais conservadora. (HIRSCHL, 2004, 198)
}

Também de uma perspectiva da teoria política normativa a juristocracia traz consequências, no mínimo, perturbadoras. Em primeiro lugar,

quando questões políticas controversas são transformadas em questões legais a massa do povo (que não são nem juízes nem juristas) é privada da oportunidade de moldar os resultados das políticas públicas de uma forma significativa e é forçada a abandonar sua responsabilidade para desenvolver soluções razoáveis e mutuamente aceitáveis acerca de questões que o divide. (HIRSCHL, 2004, 186)

Isso faz com que, em uma analogia com a constituição americana, seja necessário dizer “They, the Jurists” ao invés de "We, the People". Em segundo lugar, o processo da juristocracia indica também um problema com relação ao poder legislativo, pois ao "transferir a autoridade de tomar decisões políticas ao judiciário, esses deputados se aproveitam da vant agem (ou pior, ativamente suportam o estabelecimento e a manutenção) de um forte judiciário para evitar dificuldades e resultados impopulares ou inesperados" (HIRSCHL, 2004, 187). Em terceiro lugar, democracia exige que as escolhas de valores substantivos políticos devem ser realizados por representantes eleitos e não por juízes não-eleitos. As decisões políticas substantivas devem ser deixadas para oficiais que podem ser avaliados e responsabilizados eleitoralmente (HIRSCHL, 2004, 189), afinal, não há nenhuma prova empírica concreta de que o poder judiciário reúna de fato um conjunto de indivíduos que possuem uma intuição moral mais elaborada acerca do bem da sociedade. Assim, na juristocracia "a democracia é relegada a uma espécie de rotina eleitoral" (HIRSCHL, 2004, 221).

A crença de que os tribunais tomariam decisões ideologicamente neutras e que tendessem naturalmente a um bem comum objetivo não passaria de uma ilusão. A política possui a sua própria substância e não pode ser destruída. O que pode acontecer é que ela seja deslocada para outro âmbito e que não seja reconhecida como tal. Isso também é ressaltado por Ferrejohn:

Quando os tribunais podem tomar decisões com consequências políticas e mais ou menos finais, qualquer um com interesse nessas decisões tem o motivo para tentar expressar esses interesses na forma de argumentos jurídicos persuasivos. E aqueles interessados em decisões judiciais têm motivo para buscar influenciar e, se possível, controlar as nomeações para os tribunais e outras instituições jurídicas. Nesse sentido, a 'judicialização' da política tende a 
produzir a politização dos tribunais. Consequentemente, a tomada de decisão judicial tende a tornar-se política conduzida por outros meios. (FERREJOHN, 2012, 91)

Mas sendo esse o caso, pode-se então colocar a questão acerca da legitimidade do poder judiciário ser considerado um "poder" independente e não simplesmente um braço do executivo na aplicação das leis, tal como ocorria na modernidade. Em outras palavras, a justificação do judiciário como um poder independente ao lado do legislativo e do executivo dependia senão exclusivamente, ao menos em grande medida do pressuposto de que tal poder não deveria se envolver em assuntos legislativos e executivos, ou ainda, deveria ser um poder contramajoritário, aplicando as leis igualmente a todos de forma imparcial, mesmo quando isso fosse de encontro aos interesses da maioria.

É preciso fazer aqui uma consideração de suma importância com relação ao debate travado em torno da constitucionalização e de um modelo político no qual o judiciário é visto como o principal protagonista, a saber, de que ocorre algumas vezes nesses debates um erro argumentativo crasso. ${ }^{1} \mathrm{~A}$ argumentação na literatura em torno dessa questão parece oscilar entre dois âmbitos, um normativo e o outro descritivo, ou ainda, utilizando-se de uma terminologia moderna, existe uma oscilação injustificada entre uma argumentação que se desenvolve no âmbito do "dever ser" e outra que se desenvolve no âmbito do "ser". Com isso há uma transição de um nível para o outro sem que haja clareza das implicações e, por conseguinte, sem respeitar os devidos critérios de cada âmbito. Isso ocorre da seguinte forma: muitas vezes os argumentos que buscam legitimar o protagonismo político judiciário assumem a perspectiva de como os juristas ou juízes deveriam se comportar e compara-se isso com a forma como os legisladores se comportam de fato no parlamento. Não há dúvidas nesse caso de que a juristocracia se apresenta como uma forma atraente. Mas se compararmos o legislativo como ele deveria ser com a atuação do judiciário como ela é, então ter-se-ia uma situação ainda mais favorável do que anterior, mas agora em relação ao poder legislativo. Mas fazer esse tipo de comparação implica um equívoco fundamental. Se se quer fazer uma comparação argumentativa e logicamente coerente, então deve-se comparar o judiciário como ele "dever ser" com o legislativo tal como ele "deve ser" e, por outro lado, o judiciário como ele "é" com o legislativo tal como ele “é”. A não observação dessa distinção de âmbitos conduz a uma argumentação insustentável e falaciosa.

Outro argumento importante para retirar o poder político das cortes é apresentado por Urbinati (2014). Segundo ela, pode-se dizer que a essência normativa daquilo que deveria constituir o julgamento judicial é a imparcialidade na avaliação dos fatos e dos dados envolvidos. Os juízes não devem ser partes, devem ser externos ao caso analisado e possuem o dever legal de argumentar e de agir em nome das instituições, devendo deixar de lado seus valores e preferências pessoais. Ademais, os juízes não precisam ser politicamente representativos, ao contrário, eles devem agir apoliticamente justamente porque devem representar apenas a vontade consubstanciada no direito. O poder contido no julgamento judicial é negativo ou de controle e fiscalização, haja vista depender da vontade do soberano (o direito) e não da opinião do soberano (cf. URBINATI, 2014, p. 123s).

Por outro lado, o julgamento político deve se caracterizar pela generalidade e não pela imparcialidade. Nesse caso o critério da política deve ser o interesse geral da comunidade política. A generalidade é uma presunção a respeito da igual distribuição do poder político na sociedade. Tanto os eleitores quanto os representantes eleitos não são externos ao caso em consideração, como ocorre com os juízes ao julgar um caso. Exatamente por esta razão, não há a exigência de imparcialidade no âmbito político. Embora não haja a exigência de imparcialidade, os atores políticos devem agir com legitimidade e com responsabilidade, levando em consideração o interesse público e não apenas os interesses particulares. O julgamento político ocorre num contexto de pluralidade de opiniões e, desse modo, produz leis válidas, não leis verdadeiras. A expectativa de atuação responsável por parte dos atores políticos (cidadãos e representantes) repousa

\footnotetext{
${ }^{1}$ Agradeço a Cristina Foroni Consani por me ajudar a desenvolver esse argumento.
} 
sobre elementos como os princípios morais e constitucionais, a argumentação prudente, a ética da participação, a cultura política e também o cálculo político (cálculo das consequências da adoção de um determinado posicionamento). Urbinati ressalta que o julgamento político ganha forma dentro de um contexto pragmático, não fora ou contra tal contexto. Em outras palavras, num contexto de desacordo político cada uma das partes dissidentes possuiu razões para defender seu posicionamento e não se trata de sustentar que um posicionamento é verdadeiro e outro falso, no sentido de que o julgamento político somente poderia produzir um único resultado (cf. URBINATI, 2014, p. 123ss). Porém, essa perspectiva de um julgamento correto é esperada do juiz, uma vez que sua decisão deveria ser baseada na subsunção de um caso a lei, a qual por sua vez já se encontra definida pelo código.

Assim, a autora ressalta que a busca pela verdade no âmbito das práticas democráticas faz com que se busque uma aproximação entre o julgamento político e o judicial, tentando-se trazer para a política a imparcialidade e o consenso ao invés da generalidade e do desacordo. Tais propostas despolitizam a democracia justamente por confiarem mais em experts ou técnicos do que nos atores políticos e, desse modo, afetam a liberdade política e o direito de igual participação dos cidadãos na decisão de questões políticas relevantes, haja vista deslocarem para instituições não representativas e não submetidas ao controle popular (como, por exemplo, o poder judiciário) a decisão de questões bastante polêmicas e de grande relevância para a vida social.

Em suma, tanto da perspectiva teórica, quanto prática, a juristocracia não encontra legitimação adequada. De uma perspectiva teórica normativa (de uma justificação normativa da política e da Teoria do Estado), trazer a política para dentro dos tribunais implica: 1) colocar em cheque a teoria da divisão dos poderes; 2) minar a justificação do judiciário como um poder contra majoritário; 3) despolitizar a democracia na medida em que lhe retira a legitimidade do processo democrático; 4) confundir questões que exigem argumentos de generalidade com questões que exigem argumentos de imparcialidade; 5) impedir o aprendizado que o processo democrático traz para seus atores; 6) gerar uma espécie de despotismo indireto ${ }^{2}$, visto que os atores (juízes e cortes) não são politicamente responsabilizáveis. Já de uma perspectiva prática (das consequências da implementação da juristocracia ao longo das últimas três décadas) observou-se que: 1) há uma desconsideração aos direitos sociais, visto que o poder judiciário está atuando como uma espécie de barreira para impedir reformas democráticas que permitam uma melhor distribuição de riqueza e poder; 2) as cortes atuam em geral de modo conservador na medida em que defendem os interesses das elites hegemônicas, sejam elas políticas ou econômicas.

\section{Democracia plebiscitária}

No livro Democracia desfigurada: opinião, verdade e o povo (Democracy disfigured: opinion, truth and the people $)^{3}$, Urbinati sustenta que existem atualmente três formas de desfiguração da democracia: a democracia epistêmica ou tecnocracia; o populismo; e a democracia plebiscitária. Concentra-se aqui exclusivamente na terceira desfiguração.

Pode-se descrever a democracia plebiscitária a partir de três características: A primeira característica é de que na democracia plebiscitária o ideal de publicidade é entendido como uma transparência visual do poder mediado pela mídia. Nesse caso, a mídia apresenta e constrói uma visão da realidade sem necessariamente informar o cidadão, pois ela lhe apresenta informações seletivas elaboradas e dirigidas no intuito de impressionar as pessoas com imagens que acabam por despertar compaixão ou raiva. Surge então aquilo que a autora considera como o aspecto estético ou teatral da democracia plebiscitária. Nesse modelo o papel do fórum

\footnotetext{
${ }^{2}$ Sobre o conceito de despotismo indireto ver o bastante instrutivo ensaio de Condorcet (2013).

${ }^{3}$ Para uma análise mais detalhada desse livro ver Consani (2017).
} 
público restringe-se às seguintes funções: a aprovação e a transparência. A aprovação "é o tema central do plebiscito como sinal de investidura e confiança” (URBINATI, 2014, p. 173s). A transparência, por sua vez, surge como uma exigência em troca da aprovação, pois "se o líder pede ao povo aprovação, o povo tem o direito de pedir a exposição pública do líder” (URBINATI, 2014, p. 174). Não se trata, entretanto, da exigência de publicidade e de transparência mediada por instituições cuja responsabilidade é fiscalizar e responsabilizar governantes, em constante interação com a opinião pública dos cidadãos. Trata-se, ao invés disso, de uma transparência visual do poder, mediada pelos meios de comunicação. Isso é fomentado pelo "declínio dos partidos tradicionais, o papel da televisão na construção do consentimento político e o aumento de peso do executivo como um resultado da emergência econômica e financeira" (URBINATI, 2014, p. 172).

A segunda característica é de que a função primordial do povo e do cidadão é assistir, ou seja, cabe ao povo fazer uma espécie de julgamento visual, enquanto que para apenas alguns cabe o poder da decisão (vontade), normalmente àqueles indivíduos associados à mídia. $\mathrm{O}$ papel da mídia é ativo, enquanto que o do cidadão é passivo. Em outras palavras, os cidadãos passam a atuar e a julgar principalmente por meio daquilo que assistem, não a partir daquilo que falam em um debate com os seus concidadãos e representantes. Trata-se de modelo pós-representativo de democracia pois, por um lado, recusa-se a participação popular e a ideia de cidadania como autonomia e, por outro lado, exalta-se sobremaneira "o papel dos meios de comunicação como um fator extra-constitucional de vigilância” (URBINATI, 2014, p. 172). Diferentemente da democracia epistêmica, que busca substituir a opinião pela verdade e, também de modo distinto do populismo, que torna a opinião da maioria a vontade de todo o povo e o elemento central do poder político do Estado, a democracia plebiscitária aceita a estrutura representativa e defende os procedimentos democráticos, mas mantém a função de decisão (vontade) com poucos e o julgamento visual (opinião) com o povo. Não se trata exatamente de abdicar da democracia dos partidos políticos, mas da afirmação dos partidos "como um corpo oligárquico que deixa de ser intermediário para se tornar ocupante direto e por seu próprio interesse da política representada" (URBINATI, 2013, p. 89). Assim, a perspectiva midiática "declara o fim da ideia segundo a qual a política é uma combinação de decisão e julgamento e torna a política um trabalho de comparecimento visual de um público em relação ao qual a questão essencial é sobre a qualidade da comunicação entre o governo e os cidadãos" (URBINATI, 2014, p. 172). Desse modo, o papel da mídia é ativo enquanto o papel do cidadão é passivo. A publicidade e o marketing são elementos que se contrapõem, em certa medida, aos anseios de autonomia ou liberdade política. Trata-se da "ausência de transparência na transparência”. A mídia acaba por alimentar o público com informações seletivas, elaboradas e dirigidas no intuito de impressionar as pessoas com imagens que acabam por despertar compaixão ou raiva, e aqui reside $o$ aspecto estético ou teatral desse modelo. Contudo, tais imagens e dados estão longe de proporcionar ao povo informações a respeito das questões mais relevantes da política (cf. URBINATI, 2014, p. 210).

A terceira característica é de que a "liberdade do público" é passiva e não ativa. Tem-se então um público de espectadores guiados pela mídia, pela propaganda, pela publicidade e não um público de cidadãos guiados por procedimentos. Trata-se de uma liberdade desatada, desatrelada e descompromissada com o procedimento do debate e avaliação de informações, por conseguinte, não se trata da liberdade de um povo autônomo. "A diferença entre uma reunião plebiscitária e a cidadania democrática reside essencialmente no caráter e na função da fala ou do discurso" (URBINATI, 2014, p. 225s). Enquanto numa assembleia democrática o discurso é um direito político "que cada pessoa exerce em conjunto com outros de modo a influenciar, propor e avaliar decisões", numa reunião plebiscitária o discurso é, ao invés, "a prerrogativa da multidão que é feita de pessoas privadas que reagem ao que veem [ ], e não é por uma questão de formar uma visão política ou tomar parte no debate, mas de observar os executores agirem" (URBINATI, 2014, p. 226). Percebe-se um deslocamento do valor atribuído ao discurso para aquilo que é visto, nesse sentido, os cidadãos passam a agir mais com base naquilo que assistem passivamente do que com base em um discurso ou de um debate de boa fé. Nesse sentido, a regra das ruas, da internet ou da televisão é a regra da 
multidão, uma liberdade desatada. Surgem assim o fenômeno paradoxal das democracias contemporâneas em que surgem movimentos de protestos tão fortes em sua aparência, quanto são fracos e impotentes no impacto político para a produção de políticas. ${ }^{4}$

\section{Juristocracia midiática}

Apesar de ser um fenômeno pouco estudado no Brasil, a juristocracia pode ser identificada como estando em curso nas cortes brasileiras desde o início do século XXI. Tal como mostrou o estudo de Hirschl no contexto internacional, o breve estudo de Andrade, intitulado "O Superior Tribunal de Justiça e os ricos: a cartilha neoliberal”, publicado em 2016, mostra que também no Brasil as elites hegemônicas, uma vez que haviam sido derrotadas nas urnas, passaram a se utilizar das cortes, no caso em tela o STJ, para garantir seus interesses, mesmo que a revelia da constituição e do seu caráter protetivo dos direitos sociais.

Já o fenômeno de uma democracia plebiscitária possui raízes mais antigas no Brasil. A força da atuação política da mídia foi decisiva para a concretização do golpe de 1964, para a manutenção da ditadura militar, para o movimento diretas já, para a eleição de Collor em $1989^{5}$ e em diversos outros momentos políticos decisivos da política brasileira ${ }^{6}$. É interessante notar que Urbinati é influenciada pela análise do modelo da Itália de Berlusconi na criação da categoria de democracia plebiscitária. No caso do Brasil, além da grande mídia estar concentrada no poder de apenas 5 famílias, nos últimos anos também é preciso considerar o fenômeno de uma mídia vinculada às igrejas evangélicas.

Entretanto, aquilo que se denomina aqui de juristocracia midiática se apresenta como um fenômeno mais recente e complexo, o qual pode ser datado como surgido na última década. $O$ conceito de juristocracia midiática congrega os aspectos centrais do conceito de juristocracia de Hirschl e do conceito de democracia plebiscitária de Urbinati. Contudo, não se trata apenas de uma simples justaposição de características conceituais, mas da formação de um novo amálgama com características próprias. Ainda assim, a juristocracia midiática deve implicar senão todas, pelo menos a maior parte dos problemas indicados por ambas as categorias. Divide-se a análise em quatro aspectos.

1) O comportamento da mídia e dos funcionários do poder judiciário: Na juristocracia midiática há um modus operandi bastante peculiar entre a mídia e o poder judiciário. Por um lado, a mídia faz questão de transformar certos juízes e funcionários do poder judiciário em heróis ou personalidades públicas. Eles passam a frequentar programas de televisão, são chamados para participar de cerimônias de premiação, passam a ser entrevistados sobre assuntos de ordem política e moral de ordem geral, tornam-se manchetes de revistas, personagens de biografias, bonecos de carnaval, personagens de filmes e séries de televisão, etc. Nesse contexto, a mídia atua de forma bastante seletiva na divulgação de informação e na criação da imagem desses personagens. Isso é feito na medida em que ela faz questão de apresentar informações politicamente irrelevantes, parciais ou distorcidas, mas que assumem força de verdade, as quais estão sempre

\footnotetext{
${ }^{4}$ Exatamente por isso que as chamadas "primaveras" do início do século XXI, que no caso do Brasil foi identificado nas manifestações de 2013, não resultaram em nenhuma conquista política relevante e duradoura. Bem pelo contrário, tiveram como resultado um retrocesso democrático. É importante lembrar que o gatilho para a explosão de raiva e indignação da população foi na época o aumento da tarifa das passagens de ônibus, mas uma das causas mais substanciais foi a insatisfação provocada e, eu diria mesmo, manipulada, pelo o processo do mensalão e uma determinada forma de sua vinculação pela grande mídia. Uma análise cética e pessimista das manifestações de 2013 e da razão para o seu fracasso foi desenvolvida em Klein (2015b).

${ }^{5}$ Sobre como a Rede Globo de televisão interferiu na eleição de 1989 há um documentário produzido pelo Chanel 4 e dirigido por Simon Hartog intitulado Muito além do cidadão Kane (Byond citizen Kant, 1993).

${ }^{6} \mathrm{O}$ livro do jornalista Amorim, O quarto poder (2015), é um livro que se propõe a narrar a atuação política da Rede globo na politica brasileira.
} 
vinculadas a personalidade de um juiz em questão. Por seu turno, os funcionários do judiciário assumem o seu papel teatral e fazem da sua aparição na mídia um elemento cotidiano da sua autopropaganda como heróis. Seu trabalho passa a acontecer sob a luz das câmeras, a qual é sempre editada segundo os interesses hegemônicos. ${ }^{7}$ Estabelece-se uma simbiose entre a mídia e algumas figuras representativas do judiciário, sendo que da atuação de ambos surge a figura dos juízes heróis ou justiceiros. Essa simbiose se estabelece e perdura na medida em que ambos possuem uma agenda similar. Se essa agenda muda, a mídia desloca sua atenção para outro juiz que esteja disposto a desempenhar tal papel.

2) O modo como as decisões políticas e jurídicas são tomadas. Na juristocracia midiática há uma confusão entre os critérios do julgamento político e do julgamento jurídico. Enquanto questões políticas passam a ser decididas segundo supostos critérios de imparcialidade, as questões jurídicas passam a ser vistas segundo a perspectiva da generalidade, as quais acabam envolvendo considerações teleológicas, calculativas e prudenciais. Essa inversão é muitas vezes escondida sob o véu do linguajar técnico que faz com que decisões políticas de grande impacto não possam ser compreendidas no seu significado político real e em suas profundas implicações pelo cidadão ordinário. Acerca dessa inversão cabe aqui apontar que nem mesmo Dworkin, cuja teoria atua como um baluarte da revisão judicial e da constitucionalização dos direitos, defenderia a juristocracia em sentido estrito, muito menos a juristocracia midiática. É estranho que no Brasil um dos aspectos centrais da sua teoria pareça ser completamente desconsiderado por aqueles que pretendem usar a sua teoria para justificar o ativismo judicial, qual seja, a significativa distinção entre "princípios" e "políticas". Segundo Dworkin (2002), o direito trata de questões de princípio, enquanto que a política envolve questões de metas ${ }^{8}$. Segundo ele, não cabe ao judiciário decidir questões de metas, muito menos submeter um princípio a uma meta ${ }^{9}$. Nesse caso, por exemplo, o judiciário nunca poderia se colocar como meta o combate à corrupção, pois isso seria uma prerrogativa da atuação do legislativo e do executivo, muito menos poderia ele relativizar um direito (como o direito ao devido processo legal ou o direito a presunção da inocência) a fim de alcançar uma meta. Além disso, e se isso já não fosse o suficiente, pela forma como a mídia se envolve nessas questões, no modo pelo qual ela expõe as notícias e divulga informações, o judiciário não apenas passa a tomar decisões políticas que não lhe cabiam, como também o casuísmo e a arbitrariedade se tornam a constante na sua atuação, seja em questões jurídicas, seja em questões políticas. Esse casuísmo judicial pode ser claramente observado na conveniência com que o STF vem fazendo uso do princípio da autocontenção judicial, ou seja, não se trata apenas de avaliar quando o STF age, mas também quando ele decide convenientemente não agir, ainda que os casos em tela sejam juridicamente os mesmos.

\footnotetext{
${ }^{7}$ O processo do julgamento do Mensalão pode ser apontado como o início da juristocracia midiática no Brasil. Cf. "Com 53 sessões e quatro meses de duração, a Ação Penal 470 levou a um dos julgamentos mais longos da história do Supremo Tribunal Federal. Foi o mais midiático desde a invenção da TV — no Brasil, e possivelmente no mundo, superando mesmo o caso de O. J. Simpson, celebridade da TV americana acusada de assassinar a própria mulher. Três vezes por semana, sempre a partir das duas da tarde, suas sessões eram transmitidas, ao vivo e na íntegra, pela TV Justiça, do Poder Judiciário, e pela Globo News. À noite, uma seleção de declarações e comentários fortes ilustrava os telejornais. No dia seguinte, o assunto estava na primeira página dos jornais e, no fim de semana, nas capas das revistas semanais. Joaquim Barbosa, relator do caso, tornou-se personagem conhecido nas ruas. Máscaras de seu rosto foram lançadas para o carnaval de 2013. Nas semanas finais do julgamento, jornalistas de vários veículos especulavam sobre a hipótese de Joaquim Barbosa concorrer à Presidência da República — num país onde a oposição ao governo Lula sofreu três derrotas consecutivas desde 2002." (LEITE, 2013,9) A outra fase do desenvolvimento da juristocracia midiática ocorreu com a operação Lava jato, cujo principal personagem foi o juiz Sérgio Moro. É impossível entender os rumos da política no Brasil sem a atuação política enfatizada pela mídia dos dois principais personagens desses dois processos, o juiz da suprema corte Jair Barbosa e o juiz Sérgio Moro. Foram inúmeras as aparições midiáticas e premiações que ambas as figuras receberam. Quanto à suas atuações judiciais, tecnicamente consideradas, ambos foram fortemente criticados por importantes e renomados constitucionalistas.
}

${ }^{8} \mathrm{Cf}$. "Os argumentos de princípio são argumentos destinados a estabelecer um direito individual; os argumentos de política são argumentos destinados a estabelecer um objetivo coletivo. Os princípios são proposições que estabelecem direitos; as políticas são proposições que descrevem objetivos" (DWORKIN 2002, 141)

${ }^{9} \mathrm{Cf}$. "Defendo a tese de que as decisões judiciais nos casos cíveis, mesmo em casos difíceis (...), são e devem ser, de maneira característica, gerados por princípios, e não por políticas.” (DWORKIN, 2002, 132) 
Essa atuação casuística também poderia ser considerada uma forma de lawfare, a qual é sustentada pela propaganda midiática e na forma como as informações são apresentadas e editadas ao público, ou ainda ocultadas pelos escândalos e pela teatralidade na apresentação das notícias ou entrevistas. Nos processos, os escândalos substituem o julgamento, apresentações de PowerPoint tomam o lugar da apresentação de provas, convicções tem mais força do que o raciocínio jurídico, enfim, o próprio procedimento legal é transformado em uma encenação para funcionar como ferramenta política. Na realidade, a juristocracia midiática não é e nem pode ser sustentada como uma teoria (no sentido normativo), pois para que ela o fosse, deveria ser, no mínimo coerente. Retomando-se aqui uma consideração de Kant, poder-se-ia dizer que a juristocracia midiática pode ser considerada apenas como uma pseudo prática, pois para que fosse considerada prática (práxis) deveria ser fundamentada em uma teoria, cuja primeira condição é a coerência. ${ }^{10}$ Nesse sentido, a juristocracia midiática é, na realidade, apenas uma pseudo prática que se sustenta no âmbito jurídico por um fetichismo da interpretação, isto é, pela assunção da ideia de que o juiz é o principal e legítimo interprete da lei e de que ele possui elementos hermenêuticos que lhe garantem ir para além da lei escrita, quando, na realidade, o que ocorre é apenas a discricionariedade na tomada de decisões que "sua consciência" julga necessária, e, por outro lado, no âmbito político, por um excesso de ruído acerca das informações de fatos e questões políticas e pela precariedade do debate político.

3) O papel do cidadão na juristocracia midiática. Na juristocracia midiática as grandes decisões políticas são tomadas pelo judiciário ou são por ele protegidas no sentido de que ocorrem segundo os seus interesses ou sob a sua proteção. Essas mesmas decisões são editadas pela mídia e divulgadas como decisões morais e legítimas. Nesse caso, por um lado, é retirado do cidadão a escolha de representantes que decidirão acerca de questões políticas controversas e relevantes, o cidadão não participa do debate nem da construção de propostas. A ele cabe apenas assistir a uma encenação que não lhe informa acerca das reais questões e implicações presentes nas decisões políticas. O cidadão perde sua autonomia política na medida em que são os juízes ou promotores que tomam as decisões, os quais, por sua vez, não podem ser politicamente responsabilizados. Assim, a autonomia política é substituída pela passividade do expectador ou, no máximo, pela demonstração visual das massas na rua. O cidadão se transforma em um telespectador, um "seguidor" ou um "curtidor" dos perfis dos agentes políticos do judiciário, ou ainda, simplesmente, um manifestante de passeatas, de modo que lhe cabe apenas "apoiar" ou "demonstrar insatisfação" com aquilo que é decidido pelo judiciário em coordenação com a grande mídia. Todos esses atos se esvaem em si mesmos. Não há espaço e um meio institucional para que o cidadão possa deliberar e decidir.

4) Democracia e Estado de direito. Da perspectiva da teoria da democracia, a juristocracia midiática não é um desenvolvimento ou um aprofundamento, mas uma dupla patologia ou uma dupla desfiguração que faz com que os procedimentos e as decisões democráticas sejam cada vez mais insuladas em gabinetes técnicos para proteger os interesses da elite hegemônica, ao mesmo tempo em que isso ocorre sob a encenação de um cuidado e de uma consideração moral superior para com o interesse do povo. Também da perspectiva do Estado de direito, a juristocracia midiática se apresenta como uma dupla desfiguração. Por um lado, a atuação do judiciário não está mais atrelada à questão de uma obrigação com a neutralidade política, mas se alia a uma elite política que, ameaçada pelos procedimentos democráticos, encontra no poder judiciário uma forma de sob a "encenação democrática" bloquear reformas progressistas e garantir reformas conservadoras. Nesse contexto também é importante notar que os funcionários do judiciário, quando contrariado por decisões dos demais poderes, especialmente quando se trata de assuntos relativos ao aumento de seu poder ou de salários e privilégios, utilizam-se da sua discricionariedade e do casuísmo para chantagear os demais poderes. No Brasil não se tornou incomum que a negação de alguma solicitação do poder judiciário seja seguida pela deflagração de uma nova operação de investigação ou pelo andamento de algum processo que até o momento estava convenientemente "estagnado". Por outro lado, a juristocracia

\footnotetext{
${ }^{10}$ Sobre o conceito de teoria e prática e da sua relação intrínseca ver Kant (2002, 57s / TP AA 08: 275ff).
} 
midiática mina a legitimidade do poder judiciário como um poder independente e contramajoritário, como um poder cuja função é fiscalizar e controlar o legislativo e o executivo com o objetivo central da proteção dos direitos individuais e da segurança jurídica. Entretanto, uma vez que a juristocracia se torna midiática, os próprios funcionários do poder judiciário passam a se utilizar da mídia para lhes dar sustentação e aparência de legitimidade, mesmo quando tomam decisões que agridem garantias constitucionais básicas ou os critérios procedimentais de um processo legal justo e imparcial. Da perspectiva da teoria do Estado de Direito, a juristocracia midiática conduz ao Estado de Exceção e a barbárie. ${ }^{11}$

A juristocracia midiática teve início no Brasil com o caso do Julgamento do Mensalão e teve seu aprofundamento com a Operação Lava Jato. $\mathrm{O}$ Julgamento do Mensalão desestruturou profundamente tanto a democracia quanto as bases do Estado de Direito. Da perspectiva da democracia houve a utilização de uma estrutura do direito como instrumento de propaganda política para os partidos representantes da elite hegemônica. A utilização de um discurso técnico como instrumento político agrediu o âmbito da política, provocando uma contaminação que impediu que as verdadeiras questões políticas fossem apresentadas, debatidas e decididas. A juristocracia midiática introduziu na democracia um "vírus" que destrói seu hospedeiro, pois a democracia é um modelo político que passa a não mais tratar de questões da política, muito menos de forma política. Com isso se quer dizer que as decisões de grande impacto para as vidas dos indivíduos passaram a ser encobertas e preteridas por questões muito menos relevantes. Nesse sentido, durante meses e anos o foco do debate político deixou de ser as questões de crescimento econômico e distribuição de renda, a garantia de direitos sociais, de políticas de desenvolvimento cultural e científico, da promoção de uma maior descentralização dos investimentos entre os Estados e até mesmo a questão da garantia dos direitos individuais e do direito ao legítimo processo para uma discussão acerca da questão jurídica de se Lula sabia ou não sabia acerca do esquema do Mensalão. Ora, essa era uma questão irrelevante para a política. No contexto do julgamento do mensalão essa era uma questão jurídica que para ser respondida precisava de provas. Uma vez que não havia provas, a resposta jurídica para essa questão deveria ser "não", pois é um princípio do Estado de Direito que todos devem ser considerados inocentes até que se prove o contrário. Trazer a discussão acerca da questão de se o ex-presidente Lula sabia ou não sabia do suposto esquema para o centro do debate político no contexto da arena de um processo legal foi o mesmo que jogar uma bomba de fumaça para encobrir as questões que realmente interessam à política.

Da perspectiva do Estado de Direito, o processo do Mensalão provocou uma fissura na base do direito constitucional brasileiro, a qual continua a se alargar, podendo chegar a um completo colapso. $\mathrm{Na}$ medida em que se introduziu ad hoc uma tese, como foi a tese do "domínio do fato" para o direito penal brasileiro e no contexto de um julgamento para incriminar indivíduos, especificamente indivíduos de um determinado partido, cometeu-se uma agressão jurídica que corroeu a autoridade do direito. Essa tese do "domínio de fato" foi fortemente criticada por vários juristas importantes que apontavam que essa tese no contexto do direito brasileiro implicava uma agressão ao princípio do devido processo legal. Colocar esse princípio em cheque não significa apenas desconsiderar um elemento qualquer do sistema, mas implica minar o sustentáculo de toda a noção de direito legítimo e direito justo. Que um juiz possa errar em seu julgamento, isso faz parte da administração humana da justiça, mas que um juiz ou um colegiado de juízes decida suspender um dos princípios fundamentais sobre o qual a autoridade do direito se assenta sob a justificativa de um suposto "combate à corrupção", isso é algo moral e institucionalmente inaceitável. Uma falta que maculou toda a integridade moral da instituição.

A Lava Jato deu seguimento a esse processo de corrosão da democracia e do estado de direito. Assim como a operação Mão Limpas na Itália deixou o legado de uma década do governo corrupto e imoral de

\footnotetext{
${ }^{11}$ Por barbárie entendo aqui o conceito de estado bárbaro tal como definido por Kant, a saber, de um estado onde não há lei, apenas poder exercido por normas. Sobre isso ver Kant (2006, 224s. /Anth. AA 07:330f)
} 
Sílvio Berlusconi, cabe ver qual similar rumo precisará o Brasil amargar. Para o Estado de direito a Lava Jato é sinônimo de deturpação, descaso, violação, em suma, ela introduziu no estado brasileiro elementos de um "estado de exceção" e corroeu os fundamentos morais do poder judiciário brasileiro. O germe da atuação de Moro pode ser encontrado em um artigo seu de 2004, no qual ele defende que é legítimo ao judiciário fazer um "largo uso da imprensa", pois se não for possível condenar os investigados nos tribunais, "a opinião pública pode constituir um salutar substitutivo, tendo condições melhores de impor alguma espécie de punição a agentes públicos corruptos, condenando-os ao ostracismo" (MORO, 2004, 60). Note-se que essa justificativa distorce e corrompe qualquer legitimidade do poder judiciário enquanto uma instituição contra majoritária e garantidora dos direitos individuais e do devido processo legal. Trata-se de uma anomalia na teoria do estado de direito. Uma lista exaustiva de todas as agressões cometidas durante a operação Lava Jato extrapola os objetivos deste artigo. Como o interesse aqui é apenas apresentar as características gerais e indicar exemplos de como isso vem ocorrendo, faz-se apenas uma pequena amostragem dos casos mais conhecidos: 1. Gravação ilegal e divulgação criminosa de ligação telefônica envolvendo a então Presidenta Dilma Rousseff; 2. Gravação e divulgação ilegal do escritório de advogados, atacando diretamente o princípio da privacidade entre réu e defesa; 3 . Utilização desnecessária e descomedida do princípio da condução coercitiva; 5. Filmagem e divulgação ilegal das imagens da condução coercitiva do Ex-presidente Lula; 6. Utilização descabida do princípio da prisão preventiva; 7. Vazamento seletivo de delações para mídia; 8 . Falta do devido respeito ao direito de defesa; 9. Subversão do princípio da inocência; 10. Fim da segurança jurídica; 11. Last but not least, como escancarado pelo jornalista Glenn Greenwald, a atuação do próprio juiz como condutor do processo de investigação e acusação, por conseguinte, a destruição do critério da imparcialidade do juiz. É importante destacar que tendo sido Moro apenas um juiz de primeira instância, ele estava subordinado a órgãos superiores. O TRF da $4^{a}$ Região afastou uma representação de abuso de autoridade de Moro sob o seguinte argumento: a Lava Jato lida com "problemas inéditos [os quais] exigem soluções inéditas", ${ }^{12}$ traduzindo: as instâncias superiores do judiciário brasileiro legitimaram Moro a utilizar meios que não estavam previstos pelo direito, ou seja, ele pôde agir como se estivesse em um estado de exceção. A Lava Jato introduziu no Brasil elementos de um estado de exceção que culminou no golpe parlamentar de 2016 e continuou repercutindo nas eleições de 2018. É por isso que todas as reformas que estão ocorrendo e vão ocorrer nos próximos anos no Brasil, as quais revogam senão na forma ao menos de fato a chamada constituição cidadã de 1988, podem ser interpretadas como consequências da juristocracia midiática, associação de membros do poder judiciário com a grande mídia para fazer valer a sua agenda política.

\section{Considerações finais}

A juristocracia midiática pode ser considerada para o estado democrático de direito como uma desfiguração elevada ao expoente. Com o apoio popular criado pela mídia juntamente com a ilusão da imparcialidade e moralidade do judiciário coloca-se em xeque não apenas a democracia, mas o próprio estado de direito. A juristocracia midiática compartilha ao menos três características centrais com os movimentos fascistas

12 Cf. http://justificando.cartacapital.com.br/2016/09/24/unico-votar-pela-representacao-contra-moro-desembargadoraponta-abusos-e-partidarismo/ (acesso 01/04/2017) 
do início do século XX: o processo de isolamento político dos indivíduos; o uso extensivo da propaganda através dos meios de comunicação $;^{13} \mathrm{e}$ a colaboração do judiciário. ${ }^{14}$

$\mathrm{O}$ isolamento político ocorre exatamente pelo fato de que os debates políticos perderam espaço ${ }^{15} \mathrm{e}$ os indivíduos não mais acompanham e avaliam argumentos ou participam eles mesmos de boa fé em debates, mas assistem a encenações, tornam-se seguidores e curtidores de perfis e de postagens, ou ainda, simplesmente servem de meio para propagação de ofensas e mentiras (que são chamadas agora de fake news). Já o efeito da propaganda faz com que os fatos sejam apreendidos de forma distorcida, pois uma das teses do nazismo era a de que uma mentira dita inúmeras vezes passa a ser considerada verdade. Aqui é importante distinguir a propaganda político-partidária, a qual faz parte de todo processo democrático, da propaganda política que é insidiosamente inserida naquilo que se propõe a ser um meio de informação, naquilo que se propõe a ser jornalismo. Finalmente, uma forte atuação política do judiciário para a implantação da "moralidade", que no caso do nazismo era a chamada a moralidade do povo alemão. Nesse sentido, é importante lembrar que a constituição de Weimar nunca foi formalmente revogada, ela simplesmente deixou de ser seguida para dar lugar a "vontade do povo alemão" expressa na voz do Führer, mas que também era interpretada e realizada pelos juízes. Para aplicar isso, o judiciário alemão adotou claramente um viés antipositivista, ou seja, subordinou a formalidade dos princípios e regras do devido processo legal a fins alegadamente morais.

A superação da juristocracia midiática e de suas consequências sociais, políticas e jurídicas não se apresenta como uma empresa simples, pois requer necessariamente ao menos três grandes reformas: 1 . Uma reavaliação e desenvolvimento dos procedimentos democráticos, de modo que a democracia não se reduza a uma rotina de comparecimento eleitoral realizada esporadicamente; 2 . A substituição de uma concepção liberal de liberdade de imprensa por uma concepção republicana de liberdade de imprensa; ${ }^{16}$ e 3. Uma estrita circunscrição e avaliação externa dos poderes e da atuação do judiciário, o que significa, a meu ver, uma retomada e desenvolvimento dos ideais do positivismo jurídico, tal como estabelecidos

\footnotetext{
${ }^{13}$ Com relação aos dois primeiros elementos ver Arendt (2012).

${ }^{14}$ Sobre isso vale considerar o importante artigo de Maus: "O antipositivismo e antiformalismo primários da doutrina nazista corresponde à lógica de tais descrições funcionais. A aplicação correta do recém-criado direito nazista - supondo que este contivesse ainda 'diretivas' aplicáveis à Justiça - teria representado somente um obstáculo menor ao desenvolvimento do terror judicial do sistema nazista. Discriminações motivadas politicamente quando do tratamento de cada caso singular, como as que foram então exigidas, não são compatíveis com a vinculação a uma 'lei' qualquer, a qual esteja em vigor por um espaço mínimo de tempo. Deste modo aparecem nas 'Cartas aos Juízes' nacional-socialistas, com grande coerência, a personalidade dos juízes como uma importante garantia para a 'correta' jurisprudência, cujas tarefas 'só poderiam ser executadas por seres humanos livres, dignos, dotados de clareza interior, portadores ao mesmo tempo de um grande senso de responsabilidade e de satisfação na execução desta'; a magistratura deveria representar a 'elite da nação'. Na literatura jurídica da era nazista aparece tal crença de modo lapidar: o “juiz- rei” do povo de Adolf Hitler deve libertar-se do escravidão da literalidade do direito positivo”. Também as 'Cartas aos Juízes' tinham em vista a elite judiciária quando advertiam acerca de não se utilizar servilmente 'das muletas da lei', sustentando também que o juiz era visto como 'auxiliar direto da condução do Estado'. Na realidade revela-se aqui na forma de sua completa destruição a ligação entre legislação e independência da Justiça. Uma Justiça que não precise derivar a legitimação de suas decisões das leis vigentes torna-se no mínimo dependente face às necessidades políticas conjunturais, degradando-se a mero instrumento dos aparelhos administrativos. Este processo foi direcionado através de uma problemática moralização do conceito de direito. Deste modo aparece também em 1942, em meio à extrema perversão da Justiça alemã, a bela frase: 'O juiz representa a incorporação da consciência viva da nação”' (MAUS, 2000, 197)

${ }^{15}$ Por mais que os debates dos presidenciáveis no Brasil fossem falhos e insuficientes (devido a forma em que são organizados), ainda assim eles constituíam um momento importante para a formação do julgamento e avaliação de propostas e competências. Na eleição de 2018, a juristocracia midiática conseguiu eleger um candidato que se recusou a participar de todos os debates. Novamente aqui é importante deixar registrado: o candidato eleito recebeu apoio público e notório do mesmo juiz que utilizou todos os meios jurídicos e não jurídicos para impedir que o então principal adversário político do presidenciável não pudesse disputar a eleição. Finalmente, e se isso ainda não fosse suficiente para sinalizar a veracidade da tese de que a juristocracia midiática é um fenômeno real em curso no Brasil, o mesmo Juiz foi imediatamente convidado para ocupar um cargo no governo.
}

${ }^{16}$ Sobre o conceito de uma liberdade republicana de imprensa ver meu artigo Klein (2015a). 
pelo iluminismo moderno. Contudo, a explicação e defesa da importância de cada uma dessas reformas extrapola sobremaneira os objetivos desse artigo, por isso ficam para outra ocasião.

\section{Referência bibliográfica}

AMORIM. Paulo H. O quarto poder: uma outra história. São Paulo: Hedra, 2015.

ANDRADE, Lédio Rosa de. O Superior Tribunal de Justiça e os Ricos: a Cartilha Neo-Liberal. Florianópolis: Empório do Direito, 2016.

ARENDT, Hannah. Origens do totalitarismo. São Paulo: Companhia das Letras, 2012.

CONDORCET, Jean-Antoine-Nicolas de Caritat, maquis. Escritos político-constitucionais. Org. Trad e apresentação Amaro Fleck e Cristina F. Consani. Campinas. Editora da Unicamp, 2013.

CONSANI, Cristina F. Liberdade política e formação da opinião pública: os desafios da democracia representativa na contemporaneidade. In. Peri, v. 8, p. 119-145, 2017.

DWORKIN, Ronald. Levando os direitos a sério. Martins Fontes, 2002.

FEREJOHN, John. Judicializando a política, politizando o direito. In. MOREIRA, Luiz (Org.). Judicialização da política. São Paulo: 22 editorial, 63-96, 2012.

HIRSCHL, Ran. Towards Juristocracy: The Origins and Consequences of the New Constitutionalism. Harvard University Press, 2004.

KANT, Immanuel. Sobre o dito comum: isso pode ser correto na teoria mas não serve para a prática. In. KANT, I. À paz perpétua e outros opúsculos. Trad. Artur Morão. Edições 70, 2002.

KANT. Immanuel. Antropologia de um ponto de vista pragmático. Trad. Clélia Martins. São Paulo: Iluminuras, 2006.

KLEIN, Joel Thiago. Freedom of the Press: a Kantian Approach. Estudos Kantianos, v. 03, p. 83-92, 2015 a.

KLEIN, Joel Thiago. Reflexões Kantianas sobre o significado e a legitimidade da política. In: KLEIN, J. T. / DIAS, M. C. L. C.. (Org.). O Sujeito em Questão. 1ed.Natal: EDUFRN, 2015b, p. 267-308.

LEITE, Paulo Moreira. A outra história do Mensalão: contradições de um julgamento político. São Paulo: Geração Editorial, 2013.

MAUS, I.Judiciário como Superego da Sociedade - Sobre o papel da atividade jurisprudencial na 'sociedade órfã'. In. Novos Estudos, n. 58. Trad. Martonio Lima e Paulo Albuquerque. 2000.

MORO, Sérgio. Considerações sobre a operação Manu Pulite. In. R. CEJ, Brasília, n. 26, p. 56-62, jul./ set. 2004.

URBINATI. N. Democracy disfigured: opinion, truth and the people. Cambridge/London: Harvard University Press, 2014. 